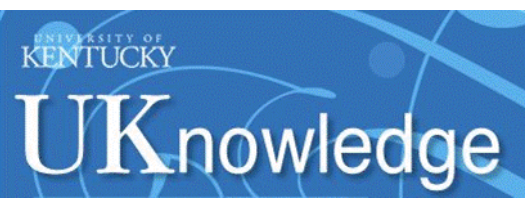

University of Kentucky

UKnowledge

\title{
Conservative Treatment for Patients with Suspected SLAP Tears: A Case Series
}

\author{
Stephanie D. Moore-Reed \\ California State University, Fresno \\ Kelley A. Seekins \\ Tennessee Wesleyan College \\ W. Ben Kibler \\ Shoulder Center of Kentucky \\ Aaron D. Sciascia \\ Eastern Kentucky University \\ Timothy L. Uhl \\ University of Kentucky, tluhl2@uky.edu
}

Follow this and additional works at: https://uknowledge.uky.edu/rehabsci_facpub

Part of the Rehabilitation and Therapy Commons

Right click to open a feedback form in a new tab to let us know how this document benefits you.

\section{Repository Citation}

Moore-Reed, Stephanie D.; Seekins, Kelley A.; Kibler, W. Ben; Sciascia, Aaron D.; and Uhl, Timothy L., "Conservative Treatment for Patients with Suspected SLAP Tears: A Case Series" (2017). Physical Therapy Faculty Publications. 70.

https://uknowledge.uky.edu/rehabsci_facpub/70

This Article is brought to you for free and open access by the Physical Therapy at UKnowledge. It has been accepted for inclusion in Physical Therapy Faculty Publications by an authorized administrator of UKnowledge. For more information, please contact UKnowledge@lsv.uky.edu. 
Conservative Treatment for Patients with Suspected SLAP Tears: A Case Series

Digital Object Identifier (DOI)

https://doi.org/10.5336/healthsci.2016-52146

Notes/Citation Information

Published in Turkiye Klinikleri Journal of Health Sciences, v. 2, issue. 2, p. 121-128.

Copyright @ 2017 by Türkiye Klinikleri

The copyright holder has granted the permission for posting the article here. 


\title{
Conservative Treatment for Patients with Suspected SLAP Tears: A Case Series
}

\author{
SLAP Yırtığı Şüphesi Olan Hastaların \\ Konservatif Tedavisi
}

Stephanie D. MOORE-REED, Kelley A. SEEKINS, ${ }^{\text {, }}$

W. Ben KIBLER, ${ }^{c}$ Aaron D. SCIASCIA, ${ }^{\text {d }}$ Timothy L. UHL ${ }^{\mathrm{e}}$

aDepartment of Kinesiology, California State University,

Fresno, USA

${ }^{\mathrm{D} T}$ Tennessee Wesleyan College,

Athens, TN, USA

'Shoulder Center of Kentucky,

Lexington, USA

dDepartment of Exercise,

Sports Science,

Eastern Kentucky University,

Richmond, USA

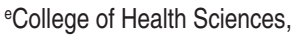

University of Kentucky,

Lexington, USA

Geliş Tarihi/Received: 01.06.2016

Kabul Tarihi/Accepted: 10.05.2017

Yazıșma Adresi/Correspondence:

Timothy L. UHL

College of Health Sciences,

University of Kentucky,

Lexington, $\mathrm{KY}$,

USA/ABD

tluhl2@uky.edu

\begin{abstract}
Objective: Outcome following non-operative management of superior labral anterior to posterior (SLAP) lesions has been under reported with little empirical data demonstrating the effectiveness of conservative treatment. Material and Methods: 10 patients, 5 matched pairs, presenting with symptoms consistent with a SLAP lesion performed a standardized phased rehabilitation program completing patient reported outcome (PRO) and pain measures before and following rehabilitation. Physical therapy notes and home exercise logs were reviewed and all exercises were recorded and coded using the phased rehabilitation protocol as a guide. At followup, patients were divided into two groups; responders and non-responders to treatment based on PRO. The volume of exercise and type of exercise performed for each patient were compared using frequency counts. Results: The non-responders did on average 33 more stretching exercises than the responders. The non-responders did on average 21 more scapular orientation exercises than the responders. There were few to no differences in the volume of strengthening exercises between the two groups except responders performed 38 more scapular retraction exercises at shoulder level while non-responders performed 49 more scapular retraction exercises below shoulder level. Conclusions: This case series identified few exercises that were beneficial to patients' responding to conservative intervention but more often identified exercises that were performed that did not facilitate an improved patient outcome. Therapeutic exercises are often the cornerstone of a rehabilitation program, yet limited evidence exists in which specific exercises are beneficial or not beneficial in patients with symptoms consistent with a SLAP lesion.
\end{abstract}

Keywords: Shoulder; outcome assessment; rehabilitation; shoulder pain

ÖZET Amaç: Superior labral anteriordan posteriora (SLAP) lezyonlarının cerrahi dışı tedavisini takiben sonuçlar konservatif tedavinin etkililiğini gösteren az sayıda ampirik verilerle bildirilmiştir. Gereç ve Yöntemler: Bir SLAP lezyonu ile uyumlu semptomlarla başvuran 10 hasta ve bunlarla eşleştirilmiş çift üzerinde rehabilitasyon öncesi ve sonrasında ağrı ölçümlerini ve hastanın sonuçlarını (PRO) tamamlayan standartlaşmış bir aşamalı rehabilitasyon programı gerçekleştirildi. Fizik tedavi notları ile ev egzersiz kayıtları gözden geçirildi ve tüm egzersizler rehabilitasyon protokolü kılavuzu kullanılarak kaydedildi ve kodlandı. Takiplerde hastalar iki gruba ayrıldı; PRO'ya dayalı tedaviye cevap verenler ve vermeyenler olarak. Her bir hasta için gerçekleşen egzersiz yoğunluğu ve egzersiz türü sıklık sayıları kullanılarak karşılaştırıldı. Bulgular: Yanıt vermeyenler, cevap verenlerden ortalama $33 \mathrm{kez}$ daha fazla germe egzersizi yapmıştır. Yanıt vermeyenler, cevap verenlerden ortalama $21 \mathrm{kez}$ daha fazla skapular oryantasyon egzersizi yapmıştır. Cevap verenler, omuz seviyesinde $38 \mathrm{kez}$ skapular retraksiyon egzersizleri yaparken, cevap vermeyenlerin omuz seviyesinin altında 49 kez skapular retraksiyon egzersizleri yapmaları dışında, iki grup arasında güçlendirme egzersiz hacminde çok az fark vardı. Sonuç: Bu vaka serisi, cevap veren gruptaki hastaların konservatif tedaviden yarar gördüğünü, fakat genellikle yapılan egzersizlerin hasta sonuçlarında fazla bir iyileşme sağlamadığını ortaya çıkarmıştır. Terapötik egzersizler çoğunlukla bir rehabilitasyon programının temel taşıdır, ancak spesifik egzersizlerin SLAP lezyonuyla uyumlu semptomları olan hastalarda yararlı olup olmadığı konusunda sınırlı kanıt bulunmaktadır.

Anahtar Kelimeler: Omuz; sonuç değerlendirmesi; rehabilitasyon; omuz ağrısı 
T

here has been an increasing incidence of surgical superior labral anterior to posterior (SLAP) repairs over the last 10 years. ${ }^{1,2}$ The management strategy for SLAP lesions is to attempt conservative management prior to undergoing surgical intervention. However, limited empirical data are available regarding non-operative management of patients with clinically diagnosed SLAP lesions.

A retrospective study of 39 patients diagnosed with SLAP lesions, at 3 years post-diagnosis, revealed that $19 / 39$ (49\%) of the patients were managed successfully with non-operative treatment and returned to normal function, with 10/15 $(67 \%)$ of athletes returning to pre-injury status. ${ }^{3}$ Sixty-eight professional baseball players diagnosed with SLAP lesion revealed a return to sport of $27 / 68(40 \%) .{ }^{4}$ Both studies provided general guidelines for rehabilitation of addressing posterior shoulder tightness, strengthening scapular musculature, and addressing other core and kinetic chain deficits. Unfortunately, the details of the prescribed rehabilitation protocol were not described, but it was clear that there were a few patients that benefited from conservative management of SLAP lesions.

A prospective study of patients clinically diagnosed with a SLAP lesion identified that 31/58 (53\%) at 6 weeks follow-up were improving to a point that the treating physician was not recommending surgical intervention. ${ }^{5}$ The primary purpose of this study was to carry out a secondary analysis of previously collected prospective data to examine the role of rehabilitation in outcome. Specifically, this study compared match pairs of patients who did and did not respond to a prospective rehabilitation intervention to determine if differences exist in the type and frequency of exercise patients performed to help clinicians determine which exercises to prescribe when treating patients with a diagnosis of SLAP tear conservatively.

\section{MATERIAL AND METHODS}

\section{STUDY DESIGN}

Matched Case Series

\section{SUBJECTS}

Patients with shoulder pain presenting to a single orthopedic surgeon's office between 2009 and 2011 were recruited to participate in a prospective intervention study. The descriptive data and characteristics of these patients have been previously reported. ${ }^{5}$ The ten patients identified in this study and their baseline characteristics are presented in Table 1. Patients were included in this study if history and physical examination were consistent with a clinical diagnosis of a SLAP lesion. At least 3 positive findings out of 4 were necessary to be included in this study.

1. Self-reported presence of to a pop or click in the shoulder, ${ }^{6,7}$

2. Positive Anterior Slide test, ${ }^{6-8}$

3. Positive modified Dynamic Labral Shear test, ${ }^{9}$

\section{Positive Active Compression test. ${ }^{7}$}

Patients were also included if they had a positive reading of a SLAP tear finding from a standard magnetic resonance imaging (MRI). Patients were excluded if during physician examination any of the following was found: numbness/tingling in the upper extremity, cervical radiculopathy, adhesive capsulitis, glenohumeral arthritis, surgery on the involved shoulder within the past year, or steroid injection within the last month. The study was approved by the University of Kentucky and Lexington Clinic Institutional Review Boards.

\section{PROCEDURES}

All patients completed the Quick Disabilities of the Arm, Shoulder, and Hand (quickDASH) and $\mathrm{Nu}-$ meric Pain Rating Scale (NPRS). The quickDASH is an 11-item questionnaire addressing symptoms and functional deficits in patients with upper extremity disorders, and is scored from 0 (no disability) to 100 (severe disability). ${ }^{10}$ The NPRS assessed the patient's worst, current, and best pain score over the past 24 hours using an 11-point scale ranging from 0 (no pain) to 10 (worst pain). ${ }^{11}$ Patient's active range of motion in flexion, internal rotation, and external rotation were measured using a digital inclinometer (Dualer, J Tech Medical, Provo UT, 


\begin{tabular}{|c|c|c|c|c|c|c|c|c|c|c|}
\hline \multirow[t]{2}{*}{ Variable } & \multicolumn{10}{|c|}{ Patient ID } \\
\hline & R1 & NR1 & R2 & NR2 & R3 & NR3 & R4 & NR4 & R5 & NR5 \\
\hline Number of Visits & 12 & 10 & 5 & 5 & 4 & 4 & 3 & 3 & 2 & 2 \\
\hline Age (years) & 50 & 55 & 47 & 32 & 46 & 45 & 51 & 43 & 44 & 54 \\
\hline Sex & $\mathrm{F}$ & $\mathrm{F}$ & $\mathrm{F}$ & $\mathrm{F}$ & M & M & M & M & M & M \\
\hline Height $(\mathrm{cm})$ & 147.3 & 167.6 & 170.2 & 175.3 & 180.3 & 177.8 & 177.8 & 175.3 & 182.9 & 172.7 \\
\hline Weight (kg) & 54.5 & 77.3 & 63.6 & 67.3 & 88.6 & 97.7 & 79.5 & 86.4 & 79.5 & 77.2 \\
\hline Injured Arm & ND & $\mathrm{D}$ & $\mathrm{D}$ & D & ND & ND & $\mathrm{D}$ & $\mathrm{D}$ & $\mathrm{D}$ & $\mathrm{D}$ \\
\hline Baseline Flexion ROM & 165.0 & 92.0 & 179.0 & 130.0 & 161.0 & 138.0 & 172.0 & 154.0 & 166.0 & 148.0 \\
\hline Baseline ER ROM & 110 & 58 & 87 & 26 & 56 & 78 & 92 & 88 & 89 & 27 \\
\hline Baseline IR ROM & 47 & 46 & 78 & 38 & 68 & 90 & 55 & 54 & 99 & 45 \\
\hline Baseline ER Strength & 14.8 & 4.0 & 3.9 & 3.0 & 11.4 & 12.5 & 9.6 & 14.9 & 9.6 & 4.8 \\
\hline Baseline Flexion Strength & 9.35 & 3.4 & 3.5 & 3.6 & 9.1 & 6.9 & 9.85 & 13.55 & 6.4 & 3.7 \\
\hline Baseline Posture & 11.8 & 12.2 & 12.4 & 13.7 & 12.8 & 19.6 & 13.1 & 15.0 & 12.2 & 14.0 \\
\hline Baseline QuickDASH & 43.2 & 45.5 & 65.9 & 56.8 & 29.5 & 25.0 & 20.5 & 27.3 & 40.9 & 38.6 \\
\hline Baseline NPRS & 5 & 5 & 7 & 5 & 2 & 2 & 5 & 4.5 & 5 & 8 \\
\hline Follow Up QuickDASH & 20.5 & 56.8 & 13.6 & 60.2 & 9.1 & 20.5 & 15.9 & 25.0 & 27.3 & 50.0 \\
\hline Follow Up NPRS & 0 & 4 & 2 & 5 & 0 & 2 & 3 & 8 & 3 & 8 \\
\hline Follow up GROC & 6 & -1 & 3 & -4 & 4 & 0 & 4 & 0 & 0 & 0 \\
\hline
\end{tabular}

$R=$ Responder; NR= Non-Responder; F= Female; M= Male; D= Dominant; ND= Non-Dominant; NPRS= Numeric Pain Rating Scale; ER= External Rotation; IR= Internal Rotation; $\mathrm{ROM}=$ Range of Motion; GROC= Global Rating of Change.

USA). Patient shoulder flexion and external rotation strength were measured with a Hand Held Dynamometer (Lafayette Instruments, Lafayette, IN, USA). All measures of shoulder rotation were performed with the patient supine and arm abducted to $90^{\circ}$ with arm supported on a $5 \mathrm{~cm}$ thick toweling.

All patients were prescribed standardized physical therapy (PT) following their initial physician office visit with the surgeon who provided a packet containing the rehabilitation protocol (Table 2). $\mathrm{Pa}-$ tients were instructed to seek out a physical therapist of their choice but requested that the rehabilitation program provided be followed. Due to patients' various residences, all physical therapy could not be performed in one location but the treating clinician could contact the research team if questions arose.

The exercise protocol was devised by a group of senior physical therapists that regularly treat non-operative and post-operative SLAP lesions. The exercise protocol was divided into four phases with each phase becoming progressively more challenging. The protocol made advancements in mobility by moving from gentle passive range of motion (ROM) exercises to static stretches into more provocative positions. The strengthening portion advanced from muscular re-education to short lever maneuvers, followed by the incorporation of long lever arm maneuvers and ceasing with ballistic exercises (similar to plyometrics). The treating physical therapist determined which phase and which particular exercises were appropriate for the patient which represents typical care.

At the follow-up appointment with the physician $(7 \pm 4$ weeks), patients completed the quickDASH, NPRS and a Global Rating of Change (GROC). The GROC is a 15-point scale ranging from -7 (a great deal worse) to zero (no change) to +7 (a great deal better). ${ }^{12}$ The change from baseline to follow-up scores was determined for the quickDASH and NPRS to evaluate patient's self-report of function and pain. Meaningful improvements were considered a change of at least 11 points on the quickDASH and at least 2 or more points on the NPRS. ${ }^{13-15}$ A score of +3 ("somewhat better") or better was considered a meaningful improvement on the GROC. ${ }^{15}$

Patients were divided into two groups based on their change scores: Responders and Non-Re- 


\begin{tabular}{|c|c|c|c|c|}
\hline Exercise Category & Level 1 & Level 2 & Level 3 & Level 4 \\
\hline Scapular Orientation & $\begin{array}{l}\text { Scapular } \\
\text { Protraction \& } \\
\text { Retraction } \\
\text { (ex. Scapular Clock) } \\
\text { Scapular \& Humeral } \\
\text { Depression } \\
\text { (ex. Inferior Glide) }\end{array}$ & & & \\
\hline \multicolumn{5}{|l|}{ Muscle Strengthening } \\
\hline Scapular Retraction & $\begin{array}{l}\text { Below Shoulder } \\
\text { Level: Isometric }\end{array}$ & $\begin{array}{l}\text { Scapular Retraction } \\
\text { Below Shoulder Level: } \\
\text { Isotonic (ex. Dynamic } \\
\text { Low Row, Lawnmower, } \\
\text { Robbery) }\end{array}$ & $\begin{array}{l}\text { Scapular Retraction } \\
\text { Isotonic at Shoulder } \\
\text { Level: Short Lever } \\
\text { Arm (ex. Pull Downs, } \\
\text { Fencing, Rows) }\end{array}$ & $\begin{array}{l}\text { Scapular Retraction } \\
\text { Isotonic (ex. Prone } \\
\text { Horizontal Abduction } \\
\text { lifts at } 90 \text {, or } 135 \text { degrees) }\end{array}$ \\
\hline Scapular Protraction & & $\begin{array}{l}\text { Scapular Protraction } \\
\text { Punch (ex. Supine Punch, } \\
\text { Scapular Punches) }\end{array}$ & $\begin{array}{l}\text { Scapular Protraction } \\
\text { Push-ups (ex. Incline) } \\
\text { Scapular Protraction } \\
\text { Punch (ex. Standing Punch) }\end{array}$ & $\begin{array}{l}\text { Scapular Protraction } \\
\text { Push-ups (ex. Knee, } \\
\text { Standard) } \\
\text { Scapular } \\
\text { Protraction Diagonal } \\
\text { (ex. Upper cut) }\end{array}$ \\
\hline Humeral Rotation & & $\begin{array}{l}\text { Humeral rotation below } \\
\text { shoulder level: Isotonic } \\
\text { (ex. IR/ER with arm at } \\
\text { side with resistance) }\end{array}$ & $\begin{array}{l}\text { Humeral Rotation at } \\
\text { Shoulder Level } \\
\text { (ex. ER/IR elastic } \\
\text { band 90/90) }\end{array}$ & $\begin{array}{l}\text { Humeral Rotation at } \\
\text { Shoulder Level } \\
\text { (ex.90/90 rotation, } \\
\text { sidelying external rotation } \\
\text { eccentrics) }\end{array}$ \\
\hline Humeral Elevation & & & $\begin{array}{l}\text { Humeral Elevation: } \\
\text { Short Lever Arm } \\
\text { (overhead press) }\end{array}$ & $\begin{array}{l}\text { Humeral Elevation: } \\
\text { Long Lever Arm } \\
\text { (ex. Flexion, Abduction, } \\
\text { Plyometrics Weighted } \\
\text { Ball Drops) }\end{array}$ \\
\hline \multicolumn{5}{|l|}{ Stretching } \\
\hline Anterior & $\begin{array}{l}\text { Supine Pectoral } \\
\text { Stretch arm at side } \\
\text { External rotation } \\
\text { (ER)-arm at side }\end{array}$ & $\begin{array}{l}\text { Supine Pectoral Stretch } \\
\text { with overpressure } \\
\text { ER with arm away } \\
\text { from side }\end{array}$ & & $\begin{array}{l}\text { Active Scapular Retraction } \\
\text { with arms at } 90\end{array}$ \\
\hline Posterior & Cross Body & & Sleeper stretch & $\begin{array}{l}\text { Sleeper stretch in more } \\
\text { abducted position }\end{array}$ \\
\hline Elevation & Table slides & Wall Slides & Latissimus dorsi stretch & $\begin{array}{l}\text { Active Latissimus } \\
\text { dorsi stretch }\end{array}$ \\
\hline & Forward Bows & Assisted Elevation with Pulley & & \\
\hline
\end{tabular}

Reprinted from Arthroscopy: The Journal of Arthroscopy and Related Surgery, 30(12), Moore-Reed SD, Kibler WB, Sciascia AD, Uhl TL, Preliminary Development of a Clinical Prediction Rule for Treatment of Patients with Suspected SLAP Tears, Pages 1540-1549, Copyright 2014, with permission from Elsevier.

sponders. Responders (positive patient reported outcome) were determined by demonstrating improvement in at least 2/3 PRO measures. Non-responders (negative patient reported outcome) were defined as patients who met 1 or none of the 3 PRO criteria. These responder criteria were modeled after the Osteoarthritis Research Society International-Outcome Measures in Rheumatology used to determine response to treatment in osteoarthritis patients. ${ }^{16}$ 
All patients were asked to submit daily logs of exercises provided to them initially along with their PT notes at their follow-up physician appointment. From the information collected, the exercises completed and the total number of PT visits was recorded. The exercises were categorized into the following: stretching, scapular orientation, strengthening, modality, or manual therapy. Each exercise was recorded and coded using the phased rehabilitation protocol. Exercises performed outside of the prescribed protocol were also recorded in order to record exercise volume and frequency performed. There were instances where the description of the exercise was unclear, requiring contact with the treating physical therapist for clarification. If the exercise in question could not be determined, it was considered a non-definable exercise.

\section{DATA ANALYSIS}

Five matched pairs of responders and nonresponders were identified based on their baseline characteristics in the following order: number of physical therapy visits, age, sex, baseline Quick DASH score, and baseline current pain level (Table 1). This minimized bias in our assessment of exercise frequency. The volume of use of modality, manual therapy, stretching exercise, and strengthening exercise were examined.

\section{RESULTS}

We compared responders to non-responders matching several factors, primarily patient visits, in order to compare exercise volume to minimize intervention bias to compare exercises more directly. There were three types of stretching exercises used, addressing all sides of the shoulder. The non-responders performed on average 33 more stretching exercises than the responders. The nonresponders were prescribed on average 21 more scapular orientation exercises than the responders. There were basically no differences in the volume of strengthening exercises between the two groups (Table 3). However, upon closer examination there

\begin{tabular}{|c|c|c|c|}
\hline Exercise Type & Responders Total Visits $=26$ & Non-Responders Total Visits $=24$ & Difference \\
\hline Modality & 2 & 7 & -5 \\
\hline Manual Therapy & 5 & 7 & -2 \\
\hline Stretching Exercises & 71 & 170 & -99 \\
\hline Anterior & 35 & 68 & -33 \\
\hline Elevation & 17 & 50 & -33 \\
\hline Posterior & 19 & 52 & -33 \\
\hline Strengthening Exercises & 223 & 263 & -40 \\
\hline Scapular \& Humeral Depression & 27 & 43 & -16 \\
\hline Scapular Protraction \& Retraction & 1 & 27 & -26 \\
\hline Elbow & 3 & 0 & 3 \\
\hline Scapula Elevation & 6 & 0 & 6 \\
\hline Humeral Elevation & 17 & 11 & 6 \\
\hline Humeral Rotation at Shoulder Level & 6 & 0 & 6 \\
\hline Humeral Rotation Below Shoulder Level & 11 & 12 & -1 \\
\hline Proprioceptive Neuromuscular Facilitation & 4 & 5 & -1 \\
\hline Scapular Protraction Diagonal & 3 & 0 & 3 \\
\hline Scapular Protraction Punch & 28 & 32 & -4 \\
\hline Scapular Protraction Push-ups & 5 & 6 & -1 \\
\hline Scapular Retraction at Shoulder Level & 60 & 22 & 38 \\
\hline Scapular Retraction Below Shoulder Level & 52 & 101 & -49 \\
\hline Eccentric Humeral Rotation Below Shoulder Level & 0 & 4 & -4 \\
\hline
\end{tabular}


appears to be a sharp contrast between responders who performed 38 more scapular retraction exercises at shoulder level and non-responders who completed 49 more scapular retraction exercises below shoulder level. The other differences were less than 10 implying meaningful difference was unlikely.

\section{DISCUSSION}

This study was conducted to describe the effectiveness of a conservative intervention of patients determined to have a clinical history consistent with a SLAP lesion. This study specifically investigated five matched pairs of patients who did and did not respond to a prospective rehabilitation intervention to determine if particular exercise type and frequency performed would help clinicians determine which exercises to prescribe when treating patients with a diagnosis of SLAP tear, conservatively. The results of the study indicate differences between the two groups. However, the results tend to suggest which interventions did not help as opposed to which interventions helped patients.

Joint mobility is a fundamental component to shoulder function with optimized shoulder function occurring when a balance between mobility and stability has been achieved. ${ }^{17}$ It was clear that there were more interventions prescribed to improve shoulder mobility in the patients who did not respond to treatment. This is not an indictment against working on shoulder mobility for these patients but is likely due to the fact that at baseline the non-responder had approximately $30^{\circ}$ less $\mathrm{ROM}$, primarily in shoulder flexion, compared to the responder group. It is logical that a physical therapist treating these patients would prescribe exercises he or she are familiar with, have had success with previously, or personally advocate to regain this mobility. It is possible that patient symptoms guided the clinicians in their selection of stretching maneuvers however; it is not clear to what extent the patients had pain during these exercises. It should be noted that at follow-up, there was no decrease in shoulder pain following the application of the physical therapy interventions. The exercises performed for anterior structure inflexibility were typically doorway and supine retraction stretches. Posterior structures were addressed using either cross body or sleeper stretches. Elevation exercises varied the most ranging from pulley, wallwalks, table slides, and latissimus dorsi stretching. It appears that simply attempting to gain motion in this population needs to be tempered relative to the level of pain the patient is experiencing and that more stretching activities do not yield superior results. In the presence of a compromised static stability system, such as in the case when a SLAP lesion is present, exercises targeting stability with less emphasis on static stretching exercises are needed. The utilization of manual therapy on the spine and shoulder has been demonstrated to have a positive effect on shoulder pain and mobility ${ }^{18,19}$. In the protocol, therapists were advised to use manual therapy, but this was rarely done or at least recorded, and the specificity of techniques was not reported.

Patients who had adequate flexibility at baseline could perhaps begin more advanced strengthening exercise initially. The responder group performed more strengthening exercises for scapular retraction at shoulder level, such as external rotation at $90^{\circ}$ or prone horizontal abduction, than did the non-responders. Although both groups of patients started with the same level of pain and disability, the non-responder group tended to focus on mobility and more scapular orientation exercises. The responders were able to focus on more challenging dynamic stability exercises as they had adequate baseline mobility. ${ }^{20}$ The primary role of the labrum is to provide some static stability but when compromised the dynamic stabilizers such as the rotator cuff must compensate for the deficit. Even with compromised static stability, the responders were able to focus on and adequately return dynamic stability to their shoulder which reduced their pain and improved their function.

One surprising result from this study was the relatively low volume of physical therapy visits. We purposefully matched responders to non-responders based on number of physical therapy visits, age, sex, baseline Quick DASH score, and baseline 
current pain level from a larger cohort of patients. The matching subsequently resulted in lower patient visit numbers. We noted that the $16 / 40$ responders on average attended physical therapy longer ( $8 \pm 6$ visits) than the non-responders $(3 \pm 3$ visits). The entire cohort could not be matched for this secondary analysis. It is clear from previous literature and is supported in part that exercise adherence is needed to hope to have a positive improvement with physical therapy. ${ }^{21-24}$

\section{LIMITATIONS}

There are limitations to the current study. This is a small matched comparison of only 10 patients therefore external validity is limited. The study was not controlled and all exercises were not supervised. While this may represent typical clinical practice where clinicians have the autonomy to develop rehabilitation programs they feel are best for each patient, the lack of control over protocol development limits our complete knowledge of what was performed for each patient. Variations in terminology used by the different therapists treating these patients on 2 exercises limited our ability to accurately classify these exercises. This represents less than 1 percent of the total exercises recorded. There was no control group but we attempted to use match comparison instead in order to attempt to compare exercises. Due to the lack of a gold standard for diagnosis of labral injury, the type of labral lesion was not verified in all patients so it is possible that the severity of the lesion could influence response. Pain medication was not recorded in these patients which could have affected patient outcomes. Additionally, the practice of the physician who participated in the study is to not use injections so we do know that no injections were received at the initial patient visit. We do not know if the patient sought out other medical care from other physicians or health care providers that may have affected the outcome. However, this is atypical. Future research should address these limita- tions, as well as control for time enrolled in physical therapy with additional follow-up information on patients, as the current study only addressed short-term improvements.

\section{CONCLUSION}

Patients with symptoms consistent with SLAP lesion were matched based on number of patient visit, age, sex, baseline QuickDASH and pain levels. Two groups were identified based on their short-term follow-up patient reported change scores and categorized as non-responders and responders to compare exercises by type and frequency. The five matched pairs revealed that non-responders did more stretching exercises and more scapular strengthening exercises below shoulder level compared to the responders who did more scapular strengthening above shoulder level. These results suggest that when the static stabilizers are compromised emphasis on dynamic stabilizers will potentially lead to improved patient reported out come in the short term.

\section{Conflict of Interest}

Authors declared no conflict of interest or financial support.

\section{Authorship Contributions}

Idea/Concept: Stephanie D. Moore-Reed, Timothy L. Uhl, W. Ben Kibler; Design: Stephanie D. Moore-Reed, Timothy L. Uhl, W. Ben Kibler, Aaron D. Sciascia, Kelley A. Seekins; Control/Supervision: Stephanie D. Moore-Reed, Timothy L. Uhl, W. Ben Kibler, Aaron D. Sciascia, Kelley A. Seekins; Data Collection and/or Processing: Stephanie D. Moore-Reed, Timothy L. Uhl, W. Ben Kibler, Aaron D. Sciascia, Kelley A. Seekins; Analysis and/or Interpretation: Stephanie D. Moore-Reed, Timothy L. Uhl, Aaron D. Sciascia, Kelley A. Seekins; Literature Review: Stephanie D. Moore-Reed, Timothy L. Uhl, Kelley A. Seekins; Writing the Article: Stephanie D. Moore-Reed, Timothy L. Uhl, W. Ben Kibler, Aaron D. Sciascia, Kelley A. Seekins; Critical Review: Stephanie D. Moore-Reed, Timothy L. Uhl, W. Ben Kibler, Aaron D. Sciascia, Kelley A. Seekins; References and Fundings: Stephanie D. Moore-Reed, Timothy L. Uhl, W. Ben Kibler; Materials: W. Ben Kibler. 
1. Weber SC, Martin DF, Seiler JG 3rd, Harrast JJ. Superior labrum anterior and posterior lesions of the shoulder: incidence rates, complications, and outcomes as reported by American Board of Orthopedic Surgery. Part II candidates. Am J Sports Med 2012;40(7): 1538-43.

2. Onyekwelu I, Khatib O, Zuckerman JD, Rokito AS, Kwon YW. The rising incidence of arthroscopic superior labrum anterior and posterior (SLAP) repairs. J Shoulder Elbow Surg 2012;21(6):728-31.

3. Edwards SL, Lee JA, Bell JE, Packer JD, Ahmad CS, Levine WN, et al. Nonoperative treatment of superior labrum anterior posterior tears: improvements in pain, function, and quality of life. Am J Sports Med 2010;38(7): 1456-61.

4. Fedoriw WW, Ramkumar P, McCulloch PC, Lintner DM. Return to play after treatment of superior labral tears in professional baseball players. Am J Sports Med 2014;42(5):115560.

5. Moore-Reed SD, Kibler WB, Sciascia AD, Uhl T. Preliminary development of a clinical prediction rule for treatment of patients with suspected SLAP tears. Arthroscopy 2014;30(12): 1540-9.

6. Michener LA, Doukas WC, Murphy KP, Walsworth MK. Diagnostic accuracy of history and physical examination of superior labrum anterior-posterior lesions. J Athl Train 2011; 46(4):343-8.

7. Walsworth MK, Doukas WC, Murphy KP, Mielcarek BJ, Michener LA. Reliability and diagnostic accuracy of history and physical examination for diagnosing glenoid labral tears. Am J Sports Med 2008;36(1):162-8.

8. Kibler WB. Specificity and sensitivity of the anterior slide test in throwing athletes with supe-

\section{REFERENCES}

rior glenoid labral tears. Arthroscopy 1995 11(3):296-300.

9. Ben Kibler W, Sciascia AD, Hester P, Dome $D$, Jacobs $C$. Clinical utility of traditional and new tests in the diagnosis of biceps tendon injuries and superior labrum anterior and posterior lesions in the shoulder. Am J Sports Med 2009;37(9):1840-7.

10. Beaton DE, Wright JG, Katz JN. Development of the QuickDASH: comparison of three itemreduction approaches. J Bone Joint Surg Am 2005;87(5):1038-46

11. Jensen MP, Karoly P, Braver S. The measurement of clinical pain intensity: a comparison of six methods. Pain 1986;27(1): 117-26.

12. Jaeschke R, Singer J, Guyatt GH. Measurement of health status. Ascertaining the minimal clinically important difference. Control Clin Trials 1989;10(4):407-15.

13. Polson K, Reid D, McNair PJ, Larmer P. Responsiveness, minimal importance difference and minimal detectable change scores of the shortened disability arm shoulder hand (QuickDASH) questionnaire. Man Ther 2010; 15(4):404-7.

14. Childs JD, Piva SR, Fritz JM. Responsiveness of the numeric pain rating scale in patients with low back pain. Spine (Phila Pa 1976) 2005;30(11):1331-4

15. Cleland JA, Childs JD, Whitman JM. Psychometric properties of the Neck Disability Index and Numeric Pain Rating Scale in patients with mechanical neck pain. Arch Phys Med Rehabil 2008;89(1):69-74

16. Pham $T$, van der Heijde $D$, Altman RD, Anderson JJ, Bellamy N, Hochberg M, et al. OMERACT-OARSI initiative: Osteoarthritis Research Society International set of respon- der criteria for osteoarthritis clinical trials revisited. Osteoarthritis Cartilage 2004;12(5): 389-99.

17. Veeger HE, van der Helm FC. Shoulder function: the perfect compromise between mobility and stability. J Biomech 2007; 40(10):211929.

18. Tate AR, McClure PW, Young IA, Salvatori $R$, Michener LA. Comprehensive impairmentbased exercise and manual therapy intervention for patients with subacromial impingement syndrome: a case series. J Orthop Sports Phys Ther 2010;40(8):474-93.

19. Boyles RE, Ritland BM, Miracle BM, Barclay DM, Faul MS, Moore JH, et al. The shortterm effects of thoracic spine thrust manipulation on patients with shoulder impingement syndrome. Man Ther 2009;14(4):37580.

20. Lippitt SB, Matsen FA. Mechanism of glenohumeral joint stability. Clin Orthop Relat Res 1993;(291):20-8.

21. Schneiders A, Zusman M, Singer K. Exercise therapy compliance in acute low back pain patients. Man Ther 1998;3(3):147-52.

22. Kolt GS, McEvoy JF. Adherence to rehabilitation in patients with low back pain. Man Ther 2003;8(2):110-6.

23. Friedrich M, Gittler G, Halberstadt Y, Cermak $T$, Heiller I. Combined exercise and motivation program: effect on the compliance and level of disability of patients with chronic low back pain: a randomized controlled trial. Arch Phys Med Rehabil 1998;79(5):475-87.

24. Shumway-Cook A, Gruber W, Baldwin M, Liao $S$. The effect of multidimensional exercises on balance, mobility, and fall risk in communitydwelling older adults. Phys Ther 1997;77(1): 46-57. 